\title{
The Function of Music Education in Preschool Children
}

\author{
He Yanyan \\ Baoji Vocational \& Technical College, Shaanxi, China,721000
}

Keywords: Music education; Preschool stage; Strategy

Abstract: Preschool education is a critical period of children's education, which is an important period to establish a correct outlook on life and values. Music is a necessity of human spiritual life. Music education in preschool can stimulate children's learning potential, which plays a positive role in cultivating children's good living habits, thinking ability and character quality. Preschool children music education must strictly follow the characteristics of children's psychological development. It is necessary to focus on the overall development of children when we talk about basic music knowledge and skills, to better promote the comprehensive development of children's body and emotion through the music education means. Based on the significance of developing music education in preschool, this paper analyzes the necessity, and then proposes optimization strategies on this basis.

\section{Introduction}

With the rapid development of social education activities, pedagogy, psychology and so on, the music education of preschool children have also undergone great changes. Since the 1940s, a unique music education system for children has been established abroad. The main content is how to effectively teach children to learn music and promote their great development on music education. The education theory and practical experience have been the main basis of music education research in preschool children all over the world.

Pre-school children music education is an indispensable part of education. It has common characteristics and particularity with the other disciplines education. There are two aspects. The first is children's music. The second one is education through music. We cannot simply understand preschool children's music education as the music education of knowledge and skills, but also breaks away the music particularity and the children's psychological development regular. We have to tie these two things together. Only in this way can we fully realize the value of preschool children's music education. Pre-school children music education is an indispensable part of pre-school education, which must be strictly in accordance with the overall goal of pre-school education. This paper makes an in-depth analysis of preschool children's music education, hoping to provide some references for many early childhood educators and parents. Only with the correct theoretical guidance, children can successfully carry out music education activities. 


\section{The function of music education in preschool children}

\subsection{Help children's physical and mental development}

The music teaching is the process of moral character and emotion education. Music with different themes and contents will have different education focus. For example, "The world is really beautiful" is a strong sense of rhythm music, it brings children happy, excited feeling. At the same time, children also dance with the rhythm of music. Which not only promotes the development of the child's brain, but also promotes the development of the child's physical coordination. "Dongdong is a coward" can make education children brave. So, it is great significance that music education can help the health development of children's physical and mental.

\subsection{Promote children's cognitive development}

Children's cognitive ability is an important part of preschool education. In Chinese children's music, there are many music imitating animals, plants, natural phenomena, humanities and social sciences. For example, 'it's a beautiful world' depicts animal forms and sounds, such as rooster, monkey, elephant, frog, penguin and so on. In the teaching process, children not only know about animals, but also learn about the forms of various animals through learning dance. At the same time, children will naturally form some pictures of these animals in their minds, which exercises their imagination. In life, children will correspond with animals, which stimulates children's ability to observe things around them. Music education is helpful for promoting children's understanding of animals, natural phenomena and social sciences.

\subsection{Promote children's cognitive development}

Music is auditory art, and music teaching is also based on auditory perception. Music education in preschool children also helps and promotes the development of children's cognitive ability. The way children express their perceptual abilities is the feeling through movement, language and expression. Music education can cultivate children's perception ability through melody, lyrics and dance. For example, the main scene in 'rain song' depicts the sound produced by rain, and then the mother takes an umbrella to pick up the child. Children are aware of the natural phenomenon of "rain". At the same time, the children experienced the maternal love through this song.

\subsection{Stimulate children's imagination and creativity}

In preschool stage, image thinking plays a major role in brain activities, and children imagine and create through this kind of image thinking. Music education can activate children's image thinking and stimulate their imagination and creativity. Preschool teachers can play different emotional contents and different rhythms of music, so as to stimulate different imaginations of different students. For example, 'song of spring girl' can let the children imagine the scene of spring, the children will have the feeling of spring immediately. In addition, the preschool teacher can also guide the children to follow the music movement. When the teacher plays a piece of rhythm cheerful music, children will dance with music, which makes children imperceptibly create. Music education can cultivate children's imagination and creativity from childhood.

\subsection{Promote children's language development}

Through a large number of practices, music education also promote the language development of 
preschool children. A good song is like a good poem. When preschool children learn an excellent song, they can not only accumulate a large number of music vocabulary, but also expand their vocabulary. Which will greatly improve their ability to use literary language.

\subsection{Help children's personality development}

Preschool children's personality development is completely different from other people's unique and overall characteristics. Individuation has become a side of preschool children's personality development, as well as a development process of psychological or physiological independence. In the preschool stage, the goal is cultivating children's attitude and interest in surrounding affairs.

\subsection{Help children's social development}

Social development is gradually formed and developed by preschool children in the communication process of nearby people. In the preschool stage, there are many opportunities for children to interact with people. People children associate with can have a huge impact on the development. Music provides children with a lot of opportunities for creative development, at the same time, it also provides a lot of opportunities for social development. When children are not completely socialized, their thoughts and behaviors are difficult to adapt to the society. If preschool children are placed in the surrounding population, their sociality will gradually form, which is also the need for future development.

\section{Strategies to improve music teaching level}

\subsection{Preschool education teacher team construction}

Although pre-school education is not included in the nine-year compulsory education, its important position in children's education is self-evident.

At present, education institutions for children in China are mostly set up by private individuals. There are very few schools that have dedicated music teachers based on cost basis. In most schools, the music teaching task is performed by non-professional teachers. There is the primary issue for strengthening the teaching staff resources. Based on the cost factor, music teaching skill training has become the most efficient and effective way. There are many ways to improve music teaching level. For example, we can support kindergarten teachers on the job qualifications education and improve the music appreciation ability of teachers.

\subsection{Innovate teaching methods and objectives}

In traditional music teaching, the teaching goal is only to teach children to sing and dance. Traditional teaching mode is single. There are always teacher mechanical and children following, and then repeated. Although this teaching method can let the children learn a song or dance at the fastest speed, it is not help for the development of children's imagination and thinking ability. The purpose of music teaching is not simply for children to learn to sing and dance. However, we should pay more attention to the cultivation of children's emotional, aesthetic, cognitive and perceptual abilities. There are important means to improve preschool music teaching effect, such as innovate teaching methods, contents and objectives. We must change the traditional teaching method into that the children are the subject of teaching activities. We can attract children's interest in learning through the interesting and active teaching model. Only in this way can the teaching effect of music be truly improved. 


\subsection{Scientific music course}

Pre-school education stage is the fastest stage for children to recognize society and accept things. Pre-school education courses should not focus on culture education, text education, mathematics education, etc. There is extremely detrimental to the overall development and growth of children. But we also can't sing, dance as a teaching focus. We should carry out interspersed teaching and reasonably arrange courses according to the psychological state of children in different periods. For example, when you arrive at school in the morning, we should have a culture education class. This allows children to learn when they are energetic. After a class, when the spirit is somewhat tired, music course can relieve the tired spirit and move the body.

\section{Conclusions}

Pre-school children music education is the aspect and element education. We should not only comply with the general goal of preschool education, but also reflect their own special rules. We should achieve the goal of teaching children music and using music for education. On the one hand, we need to let children master necessary skills through preschool children's music education. At the same time, children should learn to feel, understand and perform music. On the other hand, children should achieve comprehensive and harmonious development in physical, intellectual, emotional, personality, social and other aspects. We should promote the comprehensive, harmonious and overall development of children.

\section{References}

[1] Li feifei. A study on the value of music teaching method for preschool students [J]. Art research, 2017(01).

[2] Huang xixuan. On the role of music education in quality education [J]. Era education (education teaching),2011,(4)

[3] Liu hanjia. Investigation and research on current status of music auditory education for preschool children [D]. Nanjing university of the arts, 2011.

[4] Bai juzhen. Role of music in early childhood education [J]. Literacy: education teaching research, 2011 (43). 